\title{
PERAN MODEL PEMBELAJARAAN KOOPERATIF TIPE PICTURE AND PICTURE DALAM MENUMBUHKAN MINAT BELAJAR IPS SISWA KELAS VII D DI SMP NEGERI 1 BALONG PONOROGO
}

\author{
Wilda Ashofa ${ }^{1}$, Muhammad Widda Djuhan ${ }^{2}$ \\ ${ }^{1}$ Institut Agama Islam Negeri Ponorogo, \\ Wildaashofa2@gmail.com \\ ${ }^{2}$ Institut Agama Islam Negeri Ponorogo \\ Widdadjuhan99@gmail.com
}

\begin{abstract}
ABSTRAK
Penelitian ini dilatarbelakangi oleh metode pembelajaran tradisional yang menggunakan metode ceramah tidak melibatkan siswa aktif, sangat merugikan siswa dalam penerimaan pelajaran, siswa pasif dan cenderung sibuk sendiri berbicara dengan teman yang lain, tidak memperhatikan pembelajaran di kelas dengan baik, mengantuk dan bosan serta sebagian siswa tidak mau mengerjakan tugas pada mata pelajaran IPS. Tujuan dari penelitian ini untuk mengetahui hasil dari model pembelajaran kooperatif tipe picture and picture untuk menumbuhkan minat belajar khususnya bagi siswa kelas VII D pada mata pelajaran IPS. Maka penelitian ini difokuskan pada model pembelajaran kooperatif tipe picture and picture dalam menumbuhkan minat siswa dalam belajar IPS. Jenis dari penelitian ini merupakan penelitian lapangan yang bersifat studi kasus, teknik pengumpulan data menggunakan metode observasi, wawancara dan dokumentasi. Teknik analisis data menggunakan analisis Miles dan Huberman dengan urutan langkah reduksi data, penyajian data, dan verifikasi data. Hasil dari penelitian ini menunjukkan bahwa (1) pelaksanaan pembelajaran menggunakan model pembelajaran kooperatif tipe picture and picture sangat disukai oleh siswa karena lebih menyenangkan dan juga tidak monoton seperti menggunakan metode ceramah yang membuat peserta didik cepat merasa bosan dan bahkan tidak memperhatikan pelajaran. (2) penggunaan model pembelajaran kooperatif tipe picture and picture berhasil dalam menumbuhkan minat siswa dalam belajar IPS.
\end{abstract}

Kata kunci: Model Pembelajaran Kooperatif Tipe Picture and Picture, Minat Belajar

\section{ABSTRACT}

This research is motivated by traditional learning methods that use the lecture method which does not involve active students, it is very detrimental to students in acceptance of lessons, students are passive and tend to be busy talking to other friends by themselves, do not pay attention to learning in class properly, are sleepy and bored and some students do not. want to do assignments on social studies subjects. The purpose of this study was to determine the results of the picture and picture cooperative learning model to foster interest in learning, especially for class VII D students in social studies subjects. So this research is focused on the cooperative learning model type picture and picture in fostering student interest in learning social studies. The type of this research is field research which is case study in nature. The data collection technique uses observation, interview and documentation methods. The data analysis technique used the Miles and Huberman analysis with a sequence of data reduction steps, data presentation, and data verification. The results of this study indicate that (1) the implementation of learning using the picture and picture cooperative learning model is very liked by students because it is more fun and also not monotonous such as using the lecture method which makes students quickly feel bored and even doesn't pay attention to the lesson. (2) the use of the picture and picture 
JIIPSI: Jurnal Ilmiah Ilmu Pengetahuan Sosial Indonesia Nomor 1 Volume 1 Tahun 2021, hal 49-60

cooperative learning model succeeded in fostering student interest in learning social studies.

Keywords: the cooperative learning model type picture and picture, interest in learning

\section{PENDAHULUAN}

Pendidikan memiliki peran yang sangat penting dalam mencerdaskan kehidupan bangsa, oleh karena itu pendidikan menuntut orang-orang yang terlibat di dalamnya untuk bekerja sama secara maksimal, bertanggung jawab dan kesetiaan yang tinggi dalam meningkatkan mutu pendidikan yang lebih baik. Melalui pendidikan inilah suatu bangsa dapat menjadi bangsa yang kuat, berdikari dan berkarakter dan mampu bersaing dengan bangsa lain. Selain itu, pendidikan juga dipandang sebagai salah satu kategori yang memiliki peran utama dalam mempersiapkan sekaligus mencetak generasi muda di masa yang akan datang.

Pendidikan adalah suatu proses dengan teknik tertentu sehingga orang memperoleh pengetahuan, pemahaman dan cara bertingkah laku yang sesuai dengan kebutuhan. Sebagian masyarakat memaknai arti pendidikan sebagai pengajaran karena pendidikan secara umum selalu membutuhkan pengajaran. ${ }^{1}$

Selain itu pendidikan memiliki tujuan untuk mengembangkan bakat yang dimiliki oleh seseorang, membentuk kepribadian individu yang ahli dan kreatif serta bertaqwa kepada Tuhan Yang Maha Esa. Hal tersebut sejalan dengan UndangUndang No.20 Tahun 2003 tentang Sistem Pendidikan Nasional Bab 1 Pasal 1 (ayat 1) yang menjelaskan bahwa pendidikan adalah usaha sadar dan terencana untuk mewujudkan suasana belajar dan proses pembelajaran agar peserta didik secara aktif dapat mengembangkan potensi dirinya untuk memiliki kekuatan spritual keagamaan, pengendalian diri, kepribadian, kecerdasan, akhlak mulia, serta keterampilan yang diperlukan dirinya, masyarakat, bangsa dan negara.

Peran dan tugas guru bukan hanya sebagai penyalur ilmu pengetahuan dan wawasan bagi peserta didik tetapi guru harus menjadi agen perubahan untuk masa depan yang cemerlang dan harus menjadi suri tauladan yang baik. ${ }^{2}$

Guru adalah salah satu bagian manusia yang bertugas dalam proses pendidikan. Unsur manusiawi lainnya adalah anak didik. Guru dan anak didik berada dalam

\footnotetext{
${ }^{1}$ Muhibbin Syah, Psikologi Pendidikan dengan Pendekatan Baru, (Bandung: PT Remaja Rosdakarya, 2008), 10.

2 Zamroni, Paradigma Pendidikan Masa Depan, (Yogyakarta: BIGRAFT Publishing, 2000), 74 .
} 


\section{Peran Model Pembelajaran Kooperatif Tipe Picture And Picture dalam Menumbuhkan Minat Belajar IPS}

suatu hubungan kejiwaan. Keduannya berada dalam proses yang berhubungan dengan pendidikan dan memiliki tugas dan peranan yang berbeda. Guru yang mengajar dan mendidik dan anak didik yang belajar dengan menerima bahan pelajaran dari guru di kelas. ${ }^{3}$

Tugas utama guru adalah mengembangkan bakat dari peserta didik secara maksimal melalui penyajian mata pelajaran. Setiap mata pelajaran, dibalik materi yang di sampaikan secara jelas, mempunyai jumlah karakteristik tertentu yang mendasari materi itu sendiri. Oleh karena itu pada hakikatnya setiap guru yang menyampaikan materi harus pula mengembangkan karakter dan sifat yang mendasari mata pelajaran itu sendiri. ${ }^{4}$

Keberhasilan dari kegiatan belajar mengajar sangat dipengaruhi oleh faktor internal dan faktor eksternal dari anak didik. Faktor internal adalah faktor yang berasal dari dalam diri siswa, antara lain keaktifan dan minat belajar siswa. Salah satu faktor tersebut pendorong yang ada pada diri seseorang untuk melakukan aktivitas tertentu demi tercapainya tujuan. Keaktifan dalam kegiatan belajar dapat dikatakan sebagai keseluruhan daya penggerak di dalam diri siswa menimbulkan, menjamin dan memberikan arah kegiatan belajar., sedangkan faktor eksternal yaitu faktor yang berasal dari luar diri siswa atau berasal dari rangsangan pihak luar. Faktor tersebut antara lain metode pembelajaran dan interaksi sosial siswa.

Berdasarkan hasil observasi magang 2 di SMP Negeri 1 Balong Ponorogo. Metode pembelajaran tradisional yang menitik beratkan pada metode ceramah, tidak melibatkan siswa aktif, sangat merugikan siswa dalam penerimaan pelajaran, siswa pasif cenderung sibuk sendiri berbicara dengan teman yang lain, tidak memperhatikan pembelajaran dikelas dengan baik, mengantuk dan bosan serta sebagian siswa tidak mau mengerjakan tugas pada mata pelajaran IPS. Dari hasil wawancara dengan bapak Rudi (Guru IPS) diperoleh informasi bahwa sebagian siswa kelas ramai dan sering keluar kelas ketika mengikuti pelajaran dikarenakan kurangnya minat belajar IPS sehingga dibutuhkan pembelajaran yang inovatif dan menyenangkan. ${ }^{5}$

Dan untuk menumbuhkan minat siswa dalam belajar maka dibutuhkan suatu model pembelajaran yang tepat. Model pembelajaran adalah suatu perencanaan

\footnotetext{
${ }^{3}$ Syaiful Bahri Djamarah, Psikologi Belajar, (Jakarta: Rineka Cipta, 2000), 107.

${ }^{4}$ Zamroni, , Paradigma Pendidikan Masa Depan., 75.

${ }^{5}$ Observasi Magang 2 di SMP Negeri 1 Balong Kelas VII D
} 
atau suatu pola yang di gunakan sebagai pedoman dalam merencanakan pembelajaran di kelas atau pembelajaran dalam tutorial. Model pembelajaran mengacu pada pendekatan pembelajaran yang akan digunakan, termasuk di dalamnya tujuan-tujuan pengajaran, tahap-tahap dalam kegiatan pembelajaran, lingkungan pembelajaran, dan pengelolaan kelas. ${ }^{6}$

Pembelajaran kooperatif adalah model pembelajaran yang mengutamakan kerja sama untuk mencapai tujuan pembelajaran. Tujuan model pembelajaran kooperatif diantaranya adalah, Meningkatkan kinerja siswa dalam tugas-tugas akademik, Agar siswa dapat menerima teman-temannya yang mempunyai berbagai perbedaan latar belakang, Mengembangkan keterampilan sosial siswa; berbagi tugas, aktif bertanya, menghargai pendapat orang lain, memancing teman untuk bertannya, mau menjelaskan ide atau pendapat, dan bekerja dalam kelompok. ${ }^{7}$

Fungsi dari pemilihan model pembelajaran yang tepat senantiasa akan menumbuhkan ketertarikan atau minat dalam diri siswa untuk mengikuti pembelajaran khususnya dalam mata pelajaran IPS. Menurut Slameto, "minat adalah suatu rasa lebih suka dan suatu rasa keterikatan pada suatu hal atau aktivitas, tanpa ada yang menyuruh". Dalam hal ini, besar kecilnya minat sangat bergantung pada penerimaan akan suatu hubungan antara diri sendiri dengan sesuatu di luar dirinya. Seseorang yang berminat terhadap sesuatu, tentu akan lebih memperhatikan dengan perasaansenang tanpa ada tekanan. ${ }^{8}$

Selain pengertian-pengertian tersebut, Tidjan dalam bukunya Hariyanto mengemukakan bahwa, "minat adalah gejala psikologis yang menunjukkan pemusatan perhatian terhadap suatu objek, sebab ada perasaan senang”. Pengertian tersebut, jelas bahwa minat sebagai pemusatan perhatian atau reaksi terhadap suatu objek, seperti benda tertentu atau situasi tertentu yang didahului oleh perasaan senang terhadap objek tersebut. Slameto mengemukanan bahwa "Siswa yang memiliki minat terhadap subjek tertentu cenderung untuk memberikan perhatian yang lebih besar terhadap subjek tersebut".

\footnotetext{
${ }^{6}$ Trianto, Model Pembelajaran Terpadu Konsep, Strategi, dan Implementasinya dalam Kurikulum Tingkat Satuan Pendidikan, (Jakarta: PT Bumi Aksara, 2014), 51.

${ }^{7}$ Abdul Majid, Strategi Pembelajaran, (Bandung: PT Remaja Rosdakarya, 2014), 174.

${ }^{8}$ Slameto, Belajar dan Faktor-Faktor yang Mempengaruhinya, (Jakarta: Rineka Cipta, 2010), 180 .
} 
Peran Model Pembelajaran Kooperatif Tipe Picture And Picture dalam Menumbuhkan Minat Belajar IPS

Menurut Slameto siswa yang berminat dalam belajar mempunyai ciri-ciri sebagai berikut: Mempunyai kecenderungan yang tetap untuk untuk memperhatikan dan mengenang sesuatu yang dipelajari secara terus menerus, Ada rasa suka dan senang pada sesuatu yang diminati, Memperoleh suatu kebanggaan dan kepuasan pada sesuatu yang diminati. Ada rasa keterikatan pada sesuatu aktivitas-aktivitas yang diminati, Lebih menyukai suatu hal yang menjadi minatnya daripada yang lainnya. Dimanifestasikan melalui partisipasi pada aktivitas dan kegiatan.

Dari adanya permasalahan tersebut menggunakan metode pembelajaran picture and picture merupakan alternatif dari proses pembelajaran yang inovatif, karena dengan metode pembelajaran yang divariasikan dengan menggunakan media gambar yang disusun dengan cara berurutan menjadi urutan yang sistematis dan mengikut sertakan siswa dalam pembelajaran tersebut siswa diharapkan mampu menerima pelajaran dengan baik serta menyenangkan dan tidak membosankan serta dapat menumbuhkan minat siswa dalam belajar IPS.

Model pembelajaran picture and picture adalah suatu teknik belajar yang menggunakan gambar yang dipasangkan atau diurutkan menjadi urutan yang benar dan tepat. ${ }^{9}$

Model ini memiliki ciri aktif, inovatif, kreatif dan menyenangkan. Model pembelajaran harusnya selalu mengutamakan aktifnya siswa pada saat proses belajar mengajar. Inovatif artinya setiap pembelajaran harus membuat sesuatu yang baru, berbeda dan selalu menarik minat peserta didik. Kreatif artinya setiap pembelajaran harus dapat memunculkan minat kepada siswa untuk menghasilkan sesuatu atau dapat menyelesaikan suatu masalah dengan menggunakan metode, teknik atau cara yang dikuasai oleh siswa itu sendiri yang diperoleh dari proses pembelajaran. Model pembelajaran kooperatif tipe picture and picture menggunakan gambar sebagai media dalam proses pembelajaran.

Model pembelajaran kooperatif picture and picture memiliki beberapa ciri-ciri yaitu:

1. Aktif

\footnotetext{
${ }^{9}$ Hamdani, Strategi Belajar Mengajar, (Bandung: Pustaka Setia, 2011), 89.
} 
Dengan menggunakan model pembelajaran kooperatif picture and picture siswa atau peserta didik akan menjadi lebih aktif, hal ini dikarenakan dalam model pembelajaran ini guru menggunakan media gambar dalam memberikan pembelajaran, sehingga siswa menjadi lebih aktif dan meningkatkan rasa ingin taunya menjadi lebih besar. Selain itu dalam pelaksanaan metode ini seorang siswa juga dianjurkan untuk bisa merancang atau menggabungkan gambar sebagai media pembelajaran yang digunakan, dengan demikian siswa tidak hanya mendengarkan guru tetapi juga mengikuti pembelajaran dengan lebih aktif.

2. Inovatif

Dalam model pembelajaran picture and picture seorang siswa dan guru sebagai pengajar akan menjadi lebih aktif, hal ini dikarenakan menggunakan suatu pembaharuan dalam proses pembelajaran, tidak semata hanya guru menerangkan dan siswa yang mencatat.

\section{Kreatif}

Dalam hal ini selama proses pembelajaran dengan model picture and picture selain guru, siswa juga akan ikut menjadi lebih kreatif. Karena dalam kegiatan ini terjadi interaksi langsung antar siswa, ketika seorang guru memberikan gambar, mengacaknya, dan siswa diharapkan untuk bisa menyusunnya kembali.

Dalam kegiatan tersebut siswa diharapkan untuk bisa lebih kreatif dalam mengatasi rasa bosannya. Guru sebagai pengajar juga di tuntut untuk bisa lebih kreatif, seorang guru diharapkan mampu menyajikan sebuah gambar-gambar atau slide yang bisa membuat siswa menjadi lebih tertarik dengan proses pembelajaran.

\section{Menyenangkan}

Pada awalnya mungkin bagi beberapa guru model ini di anggap akan menimbulkan kegaduhan di dalam kelas karena terlalu banyak aktifitas siswanya. Namun bagi siswa apabila guru menerapkan model ini dalam pembelajarannya mereka akan lebih tertarik dan merasa senang selama proses belajar berlangsung. Hal ini disebabkan karena model pembelajaran picture and picture bisa juga di sebut sebagai model belajar sambil bermain, sehingga siswa tidak merasa bosan ketika proses belajar mengajar berlangsung. 
Peran Model Pembelajaran Kooperatif Tipe Picture And Picture dalam Menumbuhkan Minat Belajar IPS

Adapun keunggulan dari metode pembelajaran picture and picture sebagai berikut :

1. Metode pembelajaran ini lebih cepat, karena penyampainya dengan diskusi berkelompok, jadi dapat mengalokasi waktu.

2. Metode pembelajaran dapat menggantikan benda sebenarnya, sehingga tidak banyak benda-benda/ alat yang di bawa ke kelas (laptop dan komputer).

3. Metode pembelajaran dapat menghemat sarana sekolah.

\section{METODE PENELITIAN}

Metodologi yang digunakan dalam penelitian ini menggunakan pendekatan kualitatif, mempunyai definisi cara ilmiah guna memperpleh data yang valid (soheh) memiliki tujuan dapat ditemukan, dibuktikan serta dikembangkan suatu pengetahuan sehingga bisa dipakai untuk memahami, memecahkan dan mengantisipasi permasalahan didalam data serta memiliki tingkat akurasi yang mendalam. ${ }^{10}$

Denzin dan Lincoln menyatakan bahwa penelitian kualitatif adalah penelitian yang menggunakan latar belakang alamiah, dengan maksud menafsirkan fenomena yang terjadi dan dilakukan dengan jalan melibatkan metode yang ada dalam penelitian kualitatif. Metode yang biasanya dimanfaatkan adalah wawancara, pengamatan, dan pemanfaatan dokumen. ${ }^{11}$. Teknik pengumpulan data yang dimaksud adalah observasi, wawancara, dan dokumentasi. Bagi peneliti kualitatif menemukan fenomena melaui observasi, malalui wawancara yang mendalam untuk mendapat data yang dibutuhkan untuk penelitian, dan didukung lewat dokumentasi.Tahapan ini diawali dari mendapat kasus yang memiliki keunikan, yang mana prosesnya secara induktif, teori yang dipakai menjadi perangkat guna memandu peneliti memahami fenomena, lebih memfokuskan ke dalam daripada luasnya kajian, yang diakhiri dengan teori baru. Memiliki ntujuan untuk mendapat pemahaman yang lebih mendalam mengenai perilaku, proses interaksi, makna

10 Abdul Manab, Penelitian PendidikanPendekatan Kualitatif (Yogyakarta: Kalimedia, 2015), 1 .

11 Umar Sidiq, dan Moh. Miftachul Choiri, Metode Penelitian Kualitatif di Bidang Pendidikan (Ponorogo: CV Nata Karya, 2019), 4. 
suatu tindakan, nilai, pengalaman perseorangan maupun kelompok, yang keseluruhannya berlangsung dalam latar alami. ${ }^{12}$

Penelitian ini berjenis field reasearch, maksudnya adalah penelitian yang dilaksanakan langsung dilapangan guna mendapatkan data yang dibutuhkan. Dalam penelitian ini desain yang digunakan adalah desain penelitian studi kasus, yang mana penelitian mengfokuskan pada fenomena yang kemudian dipahami dan dianalisa secara mendalam. ${ }^{13}$

\section{HASIL DAN PEMBAHASAN}

Setiap pelaksanaan pembelajaran membutuhkan strategi atau model pembelajaran yang tepat agar peserta didik mudah untuk memahami selain itu agar tercipta pembelajaran yang menyenangkan. Model pembelajaran yang tepat harus memberikan sesuatu yang baru atau bisa mengikuti perkembangan zaman agar siswa tertarik untuk menerima pelajaran itu. Setiap model pembelajaran juga harus bisa menimbulkan minat untuk siswa agar ada rasa ingin tau lebih dalam lagi mengenai suatu pelajaran maka, harus ada minat dalam diri siswa. Karena ini sangat besar pengaruhnya terhadap keberhasilan dalam belajar. Minat siswa merupakan faktor paling penting yang menentukan tingkat dari keaktifan siswa, bila mata pelajaran yang dipelajari tidak sesuai dengan minat siswa, siswa tidak akan belajar sebaik-baiknya bahkan mereka hanya belajar asal-asalan saja, sebab tidak ada daya tarik baginya untuk belajar dan yang ada hanyalah rasa terpaksa.

Siswa yang berminat pada sebuah pelajaran akan tampak terdorong terus untuk rajin dalam belajar, berbeda dengan siswa yang sikapnya hanya menerima pelajaran, mereka hanya tergerak untuk mau belajar tetapi sulit untuk terus tekun karena tidak ada motivasinya.

Fungsi dari ketepatan memilih model pembelajaran adalah untuk mempermudah peserta didik dalam belajar dan berfikir, dan juga untu memotivasi siswa supaya menyukai suatu mata pelajaran. Fungsi lain ketepatan dalam memilih model pembelajaran yang tepat agar tidak tercipta

\footnotetext{
12 Abdul Manab, Penelitian PendidikanPendekatan Kualitatif (Yogyakarta: Kalimedia, 2015), 4.

13 Nana Saodih Sukmadinata, Metode Penelitian Pendidikan. (Bandung: PT Remaja
} Rosdakarya, 2005), 99. 
Peran Model Pembelajaran Kooperatif Tipe Picture And Picture dalam Menumbuhkan Minat Belajar IPS

kejenuhan pada saat proses belajar mengajar diperlukan kreativitas guru dalam penyampaian materi pelajaran, salah satunya dengan menggunakan model pembelajaran kooperatif tipe picture and picture.

Menurut Suprijono dalam Miftahul Huda picture and picture adalah suatu model pembelajaran yang menggunakan gambar sebagai media pembelajaran. Strategi ini mirip dengan example non example yaitu gambar yang diberikan pada siswa harus diurutkan secara benar dan tepat. Gambargambar ini menjadi hal utama dalam pembelajaran untuk itulah sebelum proses pembelajaran berlangsung guru sudah menyiapkan gambar yang akan ditampilkan baik dalam bentuk kartu atau dalam bentuk grafik berukuran besar. Gambar-gambar tersebut juga bisa ditampilkan melalui bantuan powerpoint atau software-software lain. ${ }^{14}$

Proses belajar menggunakan model pembelajaran kooperatif tipe picture and picture sangat di sukai oleh siswa karena lebih menyenangkan dan juga tidak monoton seperti menggunakan metode ceramah yang membuat siswa cepat merasa bosan dan bahkan tidak memperhatikan pelajaran. Metode ini berfungsi juga untuk mengembangkan keterampilan sosial siswa, mereka dapat berbagi tugas, bertukar pendapat, dan belajar untuk menghargai dan menerima pendapat teman yang lainnya. Model pembelajaran ini juga membuat siswa lebih antusias dalam proses pembelajaran dengan adanya gambar-gambar terasa lebih menarik karena pada dasarnya mata pelajaran IPS itu lebih mudah dipahami apabila ada gambar-gambar dan mudah untuk di ingat dibandingkan dengan metode ceramah atau yang lainnya.

Setiap model pembelajaran yang diterapkan oleh guru berfungsi untuk mencapai tujuan keberhasilan memberi pemahaman bagi setiap peserta didiknya. Guru memilih model pembelajaran berdasarkan melihat pada kemampuan dan juga kondisi para peserta didik. Joyce berpendapat: "bahwa setiap model pembelajaran mengarahkan kita dalam merancang pembelajaran untuk membantu peserta didik mencapai tujuan pembelajaran."15

14 Miftahul Huda, Model-Model Pengajaran dan Pembelajaran. (Yogyakarta: Pustaka Pelajar, 2014), 139.

${ }^{15}$ Agus suprijono, Model-Model Pembelajaran Emansipatoris, 56-57. 
Hasil dari penerapan model pembelajaran kooperatif tipe picture and picture dapat menumbuhkan minat belajar IPS pada siswa kelas VII D. Padahal sebelum diterapkan model pembelajaran tersebut banyak dari siswa enggan untuk belajar IPS mereka tidak ada motivasi dan ketertarikan. Mereka merasa bahwa belajar IPS itu membosankan dikarenakan cenderung menggunakan metode ceramah yang membuat mereka bosan dan mengantuk.

Sebelum menerapakan model pembelajaran tersebut guru menjelaskan materi terlebih dahulu secara singkat dan setelah itu guru membagi siswa menjadi empat kelompok setiap kelompok berisi 8 orang siswa dalam satu kelompok itu dibentuk dengan keterampilan yang berbeda-beda mulai yang memiliki keterampilan tinggi, sedang dan yang rendah. Setiap kelompok maju kedepan 2 siswa sebagai perwakilan kelompok. Guru memberi pertanyaan dan siswa tersebut harus secara cepat mengambil gambar-gambar yang telah disiapkan guru sebagai jawabannya lalu di tempelkan pada kertas HVS sedangkan anggota kelompok yang tidak maju kedepan dapat membantu anggotanya. Kegiatan pembelajaran berlangsung sangat menyenangkan dan tidak lagi membosankan karena semua siswa berlomba-lomba untuk mendapatkan nilai yang bagus.

Dilihat dari hal di atas sudah jelas bahwa penggunaan model pembelajaran kooperatif tipe picture and picture berhasil dalam menumbuhkan minat siswa belajar IPS. Karena mereka akan bekerja secara kelompok dapat saling membantu dan menyelesaikan permasalahan bersama. Merujuk dari hasil wawancara dengan para siswa kelas VII D pada penggunaan model pembelajaran tersebut mereka merasa senang, asik tidak lagi jenuh. Oleh sebab itu peran model pembelajaran ini dalam menumbuhkan minat belajar peserta didik dapat dilihat hasilnya.

\section{PENUTUP}

Berdasarkan hasil dari penelitian yang telah peneliti lakukan dan analisis yang telah penulis paparkan, maka dapat diambil kesimpulan sebagai berikut:

1. Pelaksanaan pembelajaran menggunakan model pembelajaran kooperatif tipe picture and picture sangat di sukai oleh siswa karena lebih 
Peran Model Pembelajaran Kooperatif Tipe Picture And Picture dalam Menumbuhkan Minat Belajar IPS

menyenangkan dan juga tidak monoton seperti menggunakan metode ceramah yang membuat siswa cepat merasa bosan dan bahkan tidak memperhatikan pelajaran. Metode ini juga membuat siswa lebih antusias dalam proses pembelajaran karena pada dasarnya mata pelajaran IPS itu lebih mudah dipahami apabila ada gambar-gambar dan akan lebih mudah untuk di ingat.

2. Penggunaan model pembelajaran kooperatif tipe picture and picture berhasil dalam menumbuhkan minat siswa belajar IPS. Karena mereka akan bekerja secara kelompok dapat saling membantu dan menyelesaikan permasalahan bersama. Merujuk dari hasil wawancara dengan para siswa kelas VII D pada penggunaan model pembelajaran tersebut mereka merasa senang, asik tidak lagi jenuh. Oleh sebab itu peran model pembelajaran ini dalam menumbuhkan minat belajar peserta didik dapat dilihat hasilnya.

\section{DAFTAR PUSTAKA}

Djamarah, Syaiful Bahri. Psikologi Belajar. Jakarta: Rineka Cipta. 2000. Hamdani. Strategi Belaja Mengajar. Bandung: Pustaka Setia. 2011.

Huda, Miftahul. Model-Model Pengajaran dan Pembelajaran. Yogyakarta: Pustaka Pelajar. 2014.

Majid, Abdul. Strategi Pembelajaran. Bandung: PT Remaja Rosdakarya. 2014.

Manab, Abdul. Penelitian Pendidikan Pendekatan Kualitatif. Yogyakarta: Kalimedia. 2015.

Sidiq, Umar dan Moh. Miftachul Choiri. Metode Penelitian Kualitatif di Bidang Pendidikan. Ponorogo: CV Nata Karya. 2019.

Slameto. Belajar dan Faktor-Faktor yang Mempengaruhinya. Jakarta: Rineka Cipta. 2010.

Sukmadinata, Nana Saodih. Metode Penelitian Pendidikan. Bandung: PT Remaja Rosdakarya. 2005.

Suprijono, Agus. Model-Model Pembelajaran Emansipatoris. Yogyakarta: Pustaka Pelajar. 2016.

Syah, Muhibbin. Psikologi Pendidikan dengan Pendekatan Baru. Bandung: PT Remaja Rosdakarya. 2008. 
JIIPSI: Jurnal Ilmiah Ilmu Pengetahuan Sosial Indonesia Nomor 1 Volume 1 Tahun 2021, hal 49-60

Trianto. Model Pembelajaran Terpadu Konsep, Strategi, dan Implementasinya dalam Kurikulum Tingkat Satuan Pendidikan. Jakarta: PT Bumi Aksara. 2014.

Zamroni. Paradigma Pendidikan Masa Depan. Yogyakarta: BIGRAFT Publishing. 2000. 